\title{
Sale and leaseback, asset outsourcing and capital market impacts
}

Article

Accepted Version

Devaney, S. and Lizieri, C. (2004) Sale and leaseback, asset outsourcing and capital market impacts. Journal of Corporate Real Estate, 6 (2). pp. 118-132. ISSN 1463-001X doi: https://doi.org/10.1108/14630010410812298 Available at https://centaur.reading.ac.uk/21501/

It is advisable to refer to the publisher's version if you intend to cite from the work. See Guidance on citing.

Published version at: http://dx.doi.org/10.1108/14630010410812298

To link to this article DOI: http://dx.doi.org/10.1108/14630010410812298

Publisher: Emerald Publications Ltd

Publisher statement: This article is ( $)$ Emerald Group Publishing and permission has been granted for this version to appear here (http://centaur.reading.ac.uk/). Emerald does not grant permission for this article to be further copied / distributed or hosted elsewhere without the express permission from Emerald Group Publishing Limited.

All outputs in CentAUR are protected by Intellectual Property Rights law, including copyright law. Copyright and IPR is retained by the creators or other copyright holders. Terms and conditions for use of this material are defined in the End User Agreement. 


\section{CentAUR}

Central Archive at the University of Reading

Reading's research outputs online 


\section{Sale and leaseback, asset outsourcing and capital-market}

\section{impacts}

(Published in the Journal of Corporate Real Estate, 6 (2): 118-132)

\section{Steven Devaney and Colin Lizieri ${ }^{\star}$}

${ }^{*}$ Centre for Real Estate Research, The University of Reading Business School, Whiteknights, Reading RG6 6AW, UK; Tel: +44 (0)118 378 8175; Fax: +44 (0)118 378 8172; E-mail: c.m.lizieri@rdg.ac.uk

\section{$<$ Double columns commence>}

Colin Lizieri is Professor of Real Estate Finance and Head of the Department of Real Estate \& Planning in the University of Reading Business School. Colin obtained his doctorate from the London School of Economics and has some 25 years of experience in real estate and related fields. His main research areas are office market modelling and financial innovation in property markets. He has acted as an adviser to many public and commercial organisations in the UK, mainland Europe, North America and Australia and has published widely in academic and professional journals.

Steven Devaney is a Research Officer at the University of Reading. His post is sponsored by Investment Property Databank and his main research areas are commercial property valuation, performance measurement and property leasing practices. Steven graduated from Reading with a first-class honours degree and worked for Ernst \& Young before returning to the University in 2002. He can be reached by e-mail at: s.p.devaney@rdg.ac.uk

\section{ABSTRACT}

Structured sale and leasebacks and corporate property asset outsourcing are often claimed to have benefits that seem to be inconsistent with financial theory. Eight such UK deals are analysed to investigate the impact on corporate value. The results show that impacts are 
contingent - on the capital structure of the firm, on the use of the capital raised and on market attitudes towards management and the sector. Two apparently similar deals can have quite different outcomes: benefits to shareholders and bondholders cannot be simply assumed.

Keywords: outsourcing, sale and leaseback, capital markets, event study

\section{$<$ Main text commences $>$}

\section{INTRODUCTION}

Much attention has been focused on the use by corporate occupiers of structured sale and leasebacks or securitised disposals of real estate assets. For instance, high-profile deals in the UK retail sector include two securitised disposals by Sainsbury's and the sale and leaseback of 78 stores by Marks \& Spencer. Great claims are made about the benefits of such activities. However, corporate finance models suggest that many of the supposed advantages could be eroded by the reaction of bondholders and shareholders to the new corporate structure. This article examines the arguments for such deals and tests if their announcement has any affect on company value using statistical techniques.

\section{OWN OR LEASE?}

The decision whether to outsource or to retain ownership of a corporate property portfolio is similar to the decision whether to buy or to lease new assets. The latter has been studied extensively in the field of corporate finance, and much theory that has been developed there is relevant to the asset outsourcing context. ${ }^{1}$ In particular, sale and leaseback transactions have traditionally been seen as a form of financing and can be analysed accordingly. Several arguments have been developed in favour of such deals, but theory suggests that not all of these arguments are valid.

Recently, there has been a movement towards new models, which involve outsourcing more than merely the ownership of property and which have a greater focus on future business requirements for space. These have been developed as new arguments for 
outsourcing have emerged, such as the need for companies to focus on their core competencies and to increase transparency of costs. The newer models and reasons for outsourcing may provide better justification for the outsourcing decision. Therefore, both traditional and recent arguments for outsourcing the ownership of real estate are now considered within the finance theory framework.

\section{Financial arguments for leasing}

Leasing gives a company an alternative method to ownership to gain use of an asset. In the UK, leases in a sale and leaseback or outsourcing deal are often structured as operating leases, although the arrangement may seem more financial in nature. ${ }^{2}$ Treatment as operating leases means that, under current UK accounting standards, the rental liability does not appear on the balance sheet. However, proposals by the UK Accounting Standards Board (ASB), if adopted, will change this, requiring all lease liabilities to be disclosed, whatever their nature.

This accounting treatment has led some people to argue that sale and leaseback disposals of property provide 'off-balance sheet financing'. As the resulting liability does not currently appear on the balance sheet, a company that outsources property may appear stronger financially than one that owns its real estate and uses debt finance. Research into the issue, though, finds that investors do take into account the liabilities of companies that enter into lease arrangements. For instance, Beattie et al. ${ }^{3}$ analysed a sample of 161 UK companies and found evidence to suggest that operating leases were reflected in equity risk. This implies that investors are aware of the underlying effects of such deals and adjust prices accordingly. Further, a firm seeking to achieve an 'optimal' capital structure can use either conventional debt or leasing with the same capital-market impact.

Another argument is that leasing provides ' 100 per cent financing'. If a company is seeking to raise capital using property assets, through outsourcing ownership, it is possible to raise an amount equivalent to the full value of the assets. In contrast, when properties are used as security for lending, most lenders impose a loan-to-value (LTV) ratio in order to protect their capital from falls in real estate values. So it would appear that, by outsourcing, 
more capital can be raised. However, the corresponding liability will also be greater and theory suggests that this will have three effects. First, the effective gearing will be higher than if debt had been used, so the required return on equity will also be higher, reducing market capitalisation. Secondly, the additional liability will restrict the ability of the company to borrow further. The extra amount gained from leasing displaces the opportunity of debt. Thirdly, the loss or ring fencing of assets can lead to pressure on ratings of the existing senior debt. ${ }^{4}$

A stronger financial argument is that capital tied up in property ownership may be put to better use within the business. The company should be able to earn a higher rate of return for shareholders by investing it in business activities. In fact, where the company's required return is greater than that generated (notionally) by the property assets, it may be argued that by holding property the company is 'destroying' value. So a firm with a required return of 20 per cent may be damaged by holding real estate assets whose value reflects a yield of, say, 8-10 per cent. This will be particularly evident to analysts employing a structured technique such as Economic Value Added, ${ }^{5}$ but it will also be evident in conventional accounting measures such as Return on Capital Employed. Capital could also be generated through raising debt on the strength of the property assets, so the potential additional benefits of outsourcing to the business must be carefully considered and priced where appropriate. Further, the property returns may be less risky than the business activity, which would be reflected in shareholders' expected returns.

\section{Operational arguments for leasing}

A major argument for outsourcing in general is that companies should focus on their core competencies. The ownership and management of property are very often outside the main functions of a business. Management time and resources could be better spent focusing on the main business functions, non-core activities being outsourced to other firms for which that activity is core. This may improve profitability, as the company can focus on areas where it has expertise and can generate higher returns. The company does lose control over the assets, however, and it is often argued that if properties house a strategic function or are 
integral to business operations then they should be retained, whether or not property is a core competency. ${ }^{6}$

Complete outsourcing of real estate functions not only transfers the assets; it also transfers the responsibility for service provision, often to a specialist provider who may be able to benefit from scale economies and expertise, lowering the overall costs of provision although this is unproven empirically. Such savings may not be available in conventional or structured sale and leasebacks, but presumably form the basis of firms' decisions. ${ }^{7}$ If total occupancy costs were lowered, there would be longer-term benefits to the income statement and for operating margins. This, in turn, has implications for future profits and expected dividend payments and should, thus, have an impact on equity and bond prices.

Outsourcing may benefit a company through risk transfer. By owning corporate real estate, a company is exposed to changes in property values, but if it leases, then those risks are borne by another party. In particular, it could be argued that a specialist real estate investor or service provider is better equipped to assess and bear the risks of property ownership. However, depending on how an outsourcing deal is structured, a company could be faced with a new source of risk from the rental market. This risk is exacerbated under traditional UK lease structures, with their long terms and upward-only rent reviews, where the occupier is exposed to cost increases in strong markets, but does not benefit from cost reductions in difficult market conditions. In some recent deals, rental risk has been reduced by negotiating fixed rent increases rather than reviews to market and by special provisions with regard to reletting.

Companies outsourcing their real estate portfolios may also be seeking greater flexibility and freedom of action. Under traditional sale and leasebacks, this may not have been achievable, the lessee being committed to a long term and having only limited and costly options for exit. Therefore, owning may have provided a more flexible option. In some recent outsourcing arrangements, however, companies have negotiated more flexible arrangements with regard to space, so that they can vacate or alter properties as their business requirements change. This enables real estate to be integrated more into the business planning cycle. Nevertheless, even with the more flexible deals, long overall 
contracts with providers are often still required in order to make the financing work. For instance, the contract between BT and Telereal is for 30 years. Where securitisation has taken place, long contracts are necessary to provide the long maturity necessary for the bonds issued to be marketable and have a low enough coupon to justify the deal. In some circumstances, this could be a constraint on a company's future actions.

\section{EXAMPLES OF ASSET OUTSOURCING AND SALE AND LEASEBACK DEALS}

To consider the impact of real estate outsourcing deals on company value, eight UK transactions carried out by six companies were selected for analysis. Their selection was influenced by a number of factors. Deals were chosen only where there was a transfer of assets to another party and the properties involved were occupational properties. Furthermore, so that the reaction to the announcement and its effect on value could be assessed, the selling organisation needed to be a quoted company.

The companies chosen for analysis were:

- Abbey National and BT, who outsourced both space and property-related services

- Marks \& Spencer and J Sainsbury's, whose outsourcing deals were funded through securitisation

- $\quad$ Kingfisher and Shell, who undertook more traditional sale and leaseback deals.

The basic characteristics of each deal are shown in Table 1. No judgment about the deals is intended in the descriptions used.

$<$ Insert Table 1 (f. 20) near here>

The Abbey National deal has received much attention because it was one of the first attempts at total property outsourcing in the private sector. ${ }^{8}$ Abbey's entire portfolio of 1,320 properties was transferred to Mapeley, who, in return, provide the bank with both property and facilities management. The structure is highly flexible, but that flexibility has come at a cost, with the initial rent roll of $£ 80$ million representing 17.5 per cent of the $£ 457$ million 
raised. The BT deal has also attracted attention, because of its sheer scale in terms of both the number of properties and the amount raised. As well as outsourcing both space and services, the purchasing vehicle, Telereal, used securitisation to raise capital.

The other deals were more traditional in structure in terms of the lease arrangements for the occupiers. There were, however, some features that differentiated them from straight sale and leasebacks. In the transaction with Topland, Marks \& Spencer negotiated vacation options, while in its other deal it pre-agreed substitutes in case its plans for the selected stores changed. In its second deal Marks \& Spencer also agreed fixed uplifts, which were also a feature of the two Sainsbury's deals, where rents are increased by 1 per cent per annum rather than reviewed to market. Securitisation was used to fund all three of these transactions. In its deal, Shell was able to agree some substitution and vacation rights.

By outsourcing real estate and taking leases in place of ownership, the capital structure of all the companies will have been affected. Balance sheet gearing may remain unaltered, but, as was argued earlier, the effective gearing will have changed and analysts will take this change into account. The effect on the value of the equity and debt can therefore be hypothesised from the change in capital structure caused by each transaction and the subsequent use of the capital raised. As the leases are long-term liabilities, theory suggests that such transactions will have a similar effect on value to raising debt.

Where the capital has been used to reduce debt, it might be expected that the effect on the equity value of the company will be fairly neutral, because one type of liability will have been substituted for another. If the capital has been put into the business or used for share buybacks, then gearing will have increased and the remaining equity will be more risky, so a fall in equity value might be expected to reflect this. If funds are reinvested in business activities, though, there may be positive effects if investors perceive that such a move will add value by earning returns above the company's cost of capital. The additional features of more recent outsourcing deals may also have an effect, if it is perceived that they too will add value to the firm's activities.

In practice, though, it may be difficult, for several reasons, to judge the 'pure' impact of outsourcing on company value. First, most of the deals took some time to be completed, 
so there is a question about when the impact should be tested. Typically, the period around the formal announcement is examined; however, information may well leak out into the market in advance of that date. Secondly, share and bond price data can be very 'noisy': random price movements and volatility may mask events. Thirdly, before and during the negotiating period there are likely to be other events happening that affect each company. These 'confounding factors' may frustrate the analysis by making it very difficult to determine what the actual impact of the real estate transaction was. Kingfisher is an extreme case: its sale and leaseback was linked to the demerger of the Woolworths retail chain, which precluded analysis of the deal.

\section{Testing market impacts}

The starting point for our analysis is the standard assumption of corporate finance that the true value of the firm is signalled by the capital market - that is, the value of the firm is the sum of the market value of the firm's equity and the market value of the firm's debt. Furthermore, the capital markets provide information on the risk of the firm relative to the market. As a result, the consequences of a corporate real estate outsourcing, a structured sale and leaseback or other restructuring should be reflected in the firm's stock-market and bond-market prices. We use statistical methods to investigate the impact of the deals outlined above.

We use two broad models to investigate capital market reactions: event study methodology and an extended single index model analysis. Both examine the change in equity and bond prices immediately before and in the period after the announcement of the restructuring. Other authors ${ }^{9}$ have used similar methods on more conventional sale and leaseback and corporate real estate decisions.

The starting point is the estimation of the expected return (price change) on the stock in each time period. For this, we use a standard single index model:

$$
\mathrm{R}_{\mathrm{it}}=\alpha+\beta_{\mathrm{i}} \mathrm{R}_{\mathrm{mt}}+\varepsilon_{\mathrm{i}}
$$


where $R_{i t}$ is the return on the firm in period $t ; \beta_{i}$ is the firm's beta (its sensitivity to overall stock-market movements); $R_{m t}$ is the return on the market index in period $t$; and $\varepsilon_{i}$ is the 'abnormal return' or residual — the return that is unique to the firm in that period and not explained by market movement. The expected (or average) value of $\varepsilon_{\mathrm{i}}$ is zero.

For most analysis of equities, $R_{m}$ is the return to the overall stock market - in the UK, a proxy for this would be the return on the FT All Share index. Over the second half of the 1990s, however, the market became increasingly segmented, the strong performance of growth stocks (in particular high-technology stocks and the dot.coms) being markedly different from that of value and defensive stocks. In the subsequent dot.com bust, value stocks relatively outperformed the previously favoured growth, technology and IT sectors. As a result, the conventional single index model often fails to explain much of the share-price movement of companies.

As a result, an alternative specification based upon sector indices is tested. Equation (1) is re-estimated using an index of General Retail, Food Retail, Bank, Oil or Telecom stocks as appropriate. The price data used are weekly and adjusted for stock splits, rights issues and dividends; they run from January 1997 to January 2003. Data series were extracted from DataStream and from data provided by the Government's Debt Management Office. Table 2 shows the results of this process. $<$ Table 2 near here $>$

Table 2: Stock betas of selected companies 1997-2003

\begin{tabular}{|l|l|l|l|l|l|}
\hline & $\begin{array}{l}\text { Proportion } \\
\text { Explained by } \\
\text { FT All Share }\end{array}$ & $\begin{array}{l}\text { Market } \\
\text { Beta }\end{array}$ & $\begin{array}{l}\text { Relevant } \\
\text { Sector Index }\end{array}$ & $\begin{array}{l}\text { Proportion } \\
\text { Explained } \\
\text { by Sector }\end{array}$ & $\begin{array}{l}\text { Sector } \\
\text { Beta }\end{array}$ \\
\hline Abbey National & $23.4 \%$ & 1.13 & Banking & $54.2 \%$ & 1.03 \\
\hline British Telecom & $20.6 \%$ & 1.13 & Telecom & $48.9 \%$ & 0.78 \\
\hline Kingfisher & $16.2 \%$ & 0.93 & Gen. Retail & $53.4 \%$ & 1.24 \\
\hline Marks \& Spencer & $15.8 \%$ & 0.95 & Gen. Retail & $56.8 \%$ & 1.24 \\
\hline J Sainsbury's & $3.1 \%$ & 0.33 & Food Retail & $56.2 \%$ & 1.08 \\
\hline Shell Trading & $28.2 \%$ & 1.03 & $\begin{array}{l}\text { Oil } \\
\text { Integrated }\end{array}$ & $79.3 \%$ & 1.06 \\
\hline
\end{tabular}

For most firms, the sector indices offer much higher levels of explanation than does the overall stock market index. For example, Sainsbury's price variations are weakly explained by the stock market but strongly explained by the Food Retailing sector. For other 
firms, the results are consistent with similar studies and with prior research on market and specific risk.

Figure 1 Time windows in event study

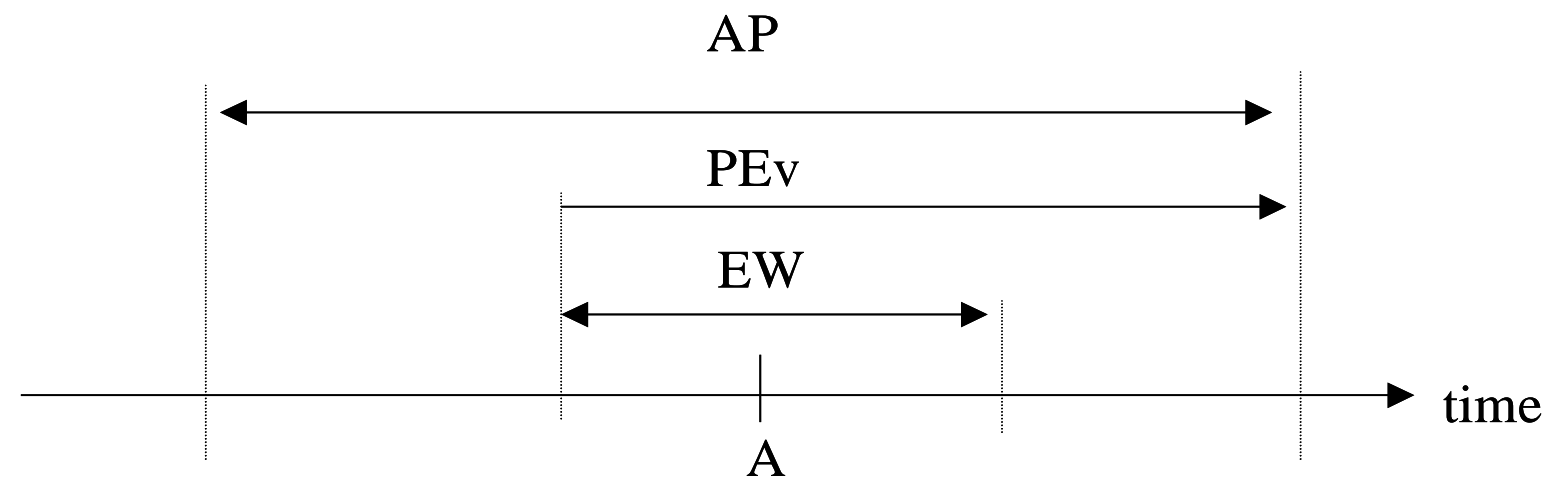

$$
\begin{array}{ll}
\mathrm{AP} & =\text { analysis period } \\
\mathrm{PEV} & =\text { post event period } \\
\mathrm{EW} & =\text { event window } \\
\mathrm{A} & =\text { announcement date }
\end{array}
$$

The next step is to specify an 'event window'. This is the time around the announcement of the restructuring. Event studies assume that information 'leaks' into the market place in advance of the announcement and that the market processes the information swiftly, changing prices as appropriate. With property announcements, it is here assumed that there may be considerable leakage in advance of the formal announcement. After testing various specifications, the present authors have used a ten-week window that runs for four weeks in advance of the announcement week and five weeks after the announcement week (see Figure 1).

\section{$<$ Figure 1 near here>}

In the event study, attention is focused on the residual returns in the event-window period. Given that the expected or average value of the residual returns over the whole analysis period is zero, we can examine the residual returns in the event window alone to gauge market reaction. If the market feels the announcement adds to the overall value of the company, then residual returns will be positive (that is, the share or bond price will have 
increased by more than expected). By contrast, if the news is considered unfavourable, then stock prices will fall by more than is expected, giving negative, abnormal, returns. These individual abnormal returns and the cumulative abnormal return (CAR) - the sum of the residual returns over the event window - are then examined, being tested to see whether they are statistically significant.

Where the announcement points to a change in the capital structure of the firm, this may affect the overall risk of shares relative to the market. For example, a sale and leaseback in effect increases the gearing of a firm, which in turn increases the volatility of equity returns. As a result, shareholders may demand higher returns - reflected in an increase in the firm's beta. To test this, an extended version of the market model from equation (1) is run:

$$
R_{i t}=\alpha+P E v+\beta_{i} R_{m t}+\beta_{j} R_{m t}^{*} P E v+\varepsilon_{i}
$$

$\mathrm{PEv}$ is a (dummy) variable indicating that the return occurs in or after the event window - that is, when the market has knowledge of the proposed change. $\beta_{\mathrm{i}}$ represents the firm's beta before the announcement and $\left(\beta_{i}+\beta_{\mathrm{j}}\right)$ represents the firm's beta after the announcement. If $\beta_{\mathrm{j}}$ is positive, then shareholders perceive the company to be more risky than before and demand a higher return for holding equity in the firm.

The same analyses are conducted for bonds as for equities, although the interpretation is not so straightforward. An unexpected increase in bond prices relative to overall bond-price movements (here proxied by the change in prices in a broad index of government securities) suggests that the firm's bonds are considered less risky - that bondholders require lower coupon rates. However, the interpretation of the betas in equations (1) and (2) is less straightforward - it is, in effect, a measure of the firm's sensitivity to interest-rate shocks.

\section{RESULTS}


In this section, each of the case studies is examined in turn, using both the event study and single index models described above. The authors analyse change in each firm's stockmarket equity prices and, where possible, changes in the price of a representative corporate bond issued by the company.

\section{Abbey National}

The Mapeley deal to take over Abbey National's operational property commitments needs to be seen as part of a wider restructuring of the firm in the light of takeover discussions and rumours. Share-price movements are particularly sensitive to takeover rumours - and to the trading performance that fuels such rumours. The property outsourcing could thus be interpreted as action aimed at fending off takeover bids - by propping up equity prices through return of cash to shareholders; by utilising the cash to strengthen trading position; or even, as was suggested, by creating a 'poison pill'.

Examining the cumulative abnormal returns from the single index model suggests that shareholders reacted relatively positively to Abbey National during the announcement period - the results being statistically significant. However, the results of examining the abnormal returns on the basis of an index of banking sector stocks are somewhat less clear. Using both extended-market and sector models, there is no evidence that shareholders considered Abbey National either more or less risky after the announcement; the beta remains unchanged in the post-event period.

$<$ Figure 2 (f. 12) near here> 
Figure 2 Abbey National cumulative abnormal equity returns ${ }^{10}$

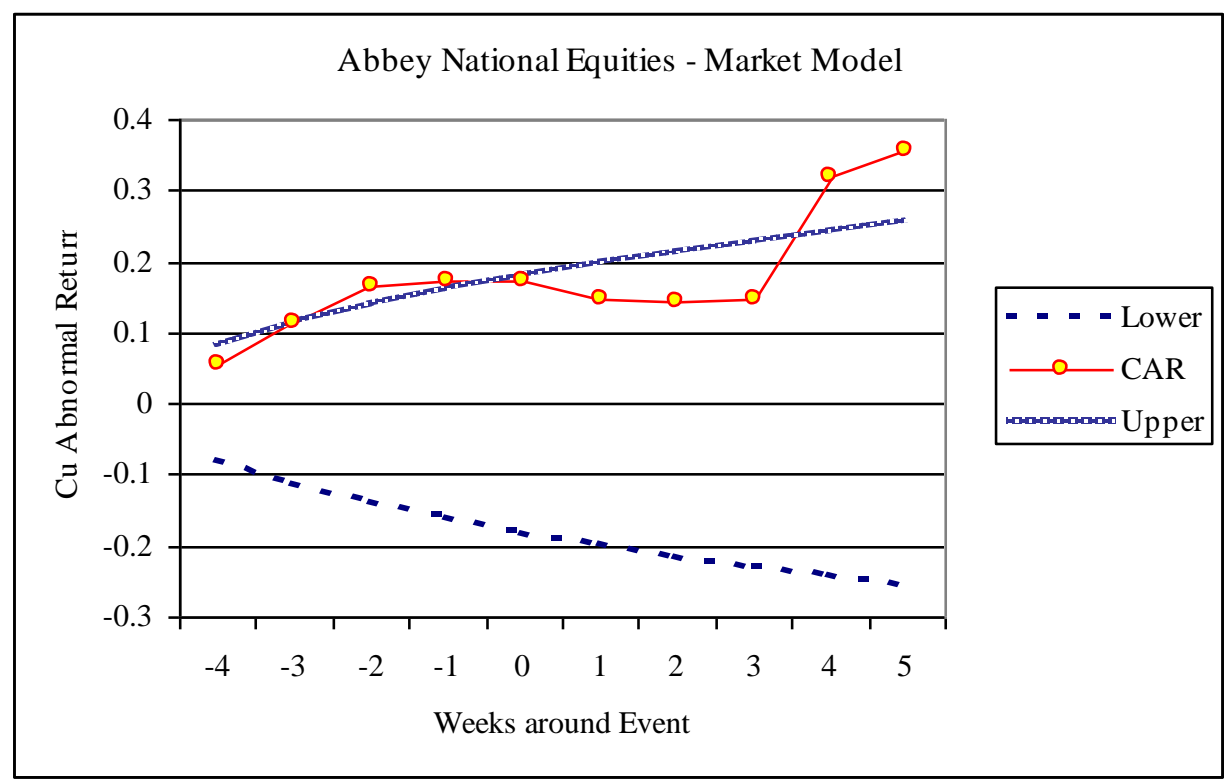

Bondholder reaction to the deal might be expected, in isolation, to be more negative.

The outsourcing removes some of the security for debt holders in the event of default, while the additional leases represent an effective increase in gearing and raise issues concerning bankruptcy costs. However, if reinvesting capital raised in the business improves earnings potential, then this may improve security of interest cover. Finally, the takeover rumours open the possibility of the debt being assumed by a bank with a higher credit rating. Abnormal price movements around the announcement date are positive and significant, suggesting that bondholders looked favourably on the company in this period.

\section{$<$ Figure 3 (f. 13) near here>}

In summary, there is weak evidence from the capital markets that the Abbey National outsourcing was viewed favourably and that both bonds and share prices were higher than expected around the time of the announcement. It is difficult to distinguish between the effects of the outsourcing and other moves by the bank in this period. 
Figure 3 Abbey National cumulative abnormal bond returns

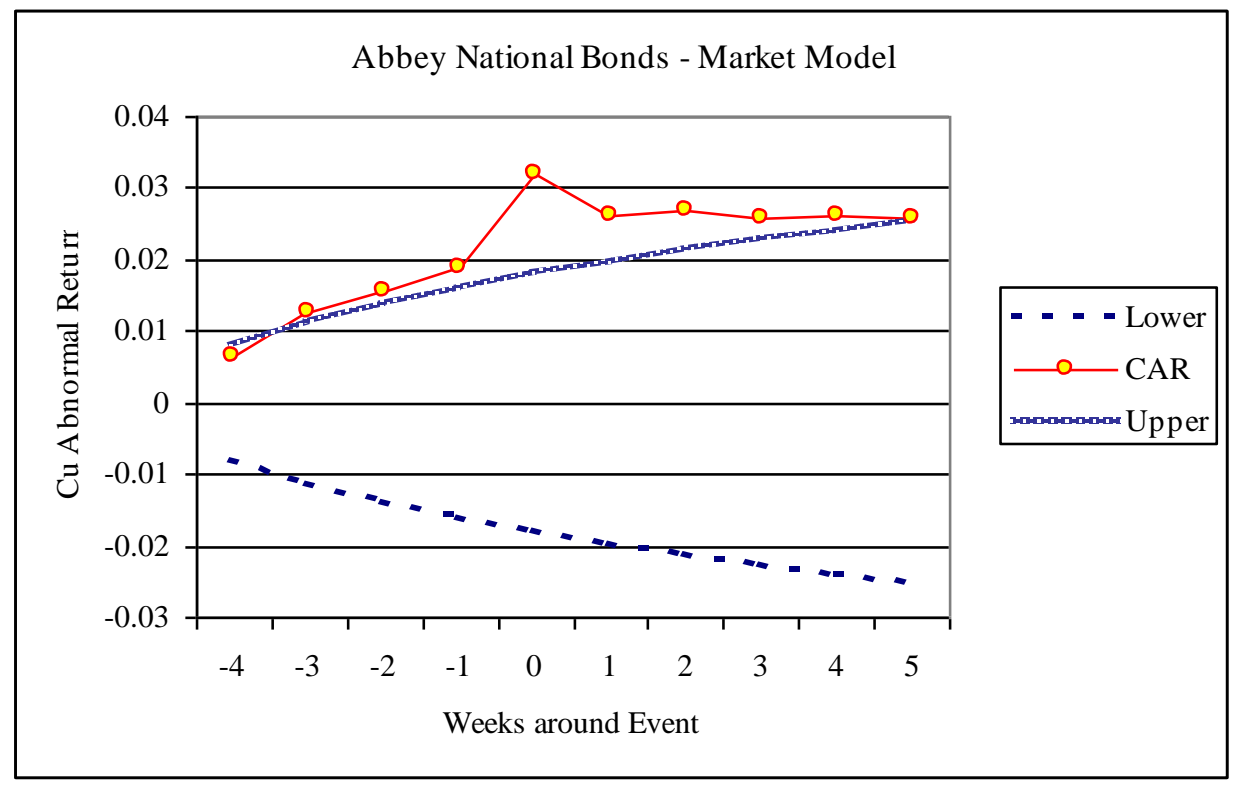

\section{British Telecommunications (BT)}

The Telereal deal also represents a near-total outsourcing of operational property, BT raising some $£ 2.3$ billion. The proceeds were largely used to resolve the company’s cash position and to buy down debt but, as noted above, the lease liabilities incurred are, in effect, another form of debt, leaving the gearing position more neutral than was portrayed. Analysis is made difficult by the long spread between rumours and completion. BT declared its intention in January 2001 (and there had been discussions long in advance of this). The preferred bidder was announced in April 2001 (we have taken this to be the firm announcement point), with agreement for sale occurring in June and practical completion in December of 2001. The deal period coincides with a rights issue and with the demerger of $\mathrm{MMO} 2$, both of which would have affected capital structure and income prospects.

There is little discernible evidence of the outsourcing having any impact on BT's equity prices. Although some abnormal returns are significant using the market model, there are both positive and negative results, which cancel out when considering the cumulative returns. The same holds for the sector model: the outsourcing does not seem to have affected share prices. By contrast, the deal appears to have had a positive impact on bond prices. This might be attributable to the resolution of the immediate cash position and, thus, the risk of default or delinquency. Although some of the cash was used to redeem existing 
debt, the remaining debt holders have lost fixed-asset security and BT has incurred new liabilities in the form of the operating leases. Nonetheless, actual bond prices are higher than the values predicted, using the market model with change in gilt prices as the reference index.

$<$ Figure 4 near here>

Figure 4 BT cumulative abnormal bond returns

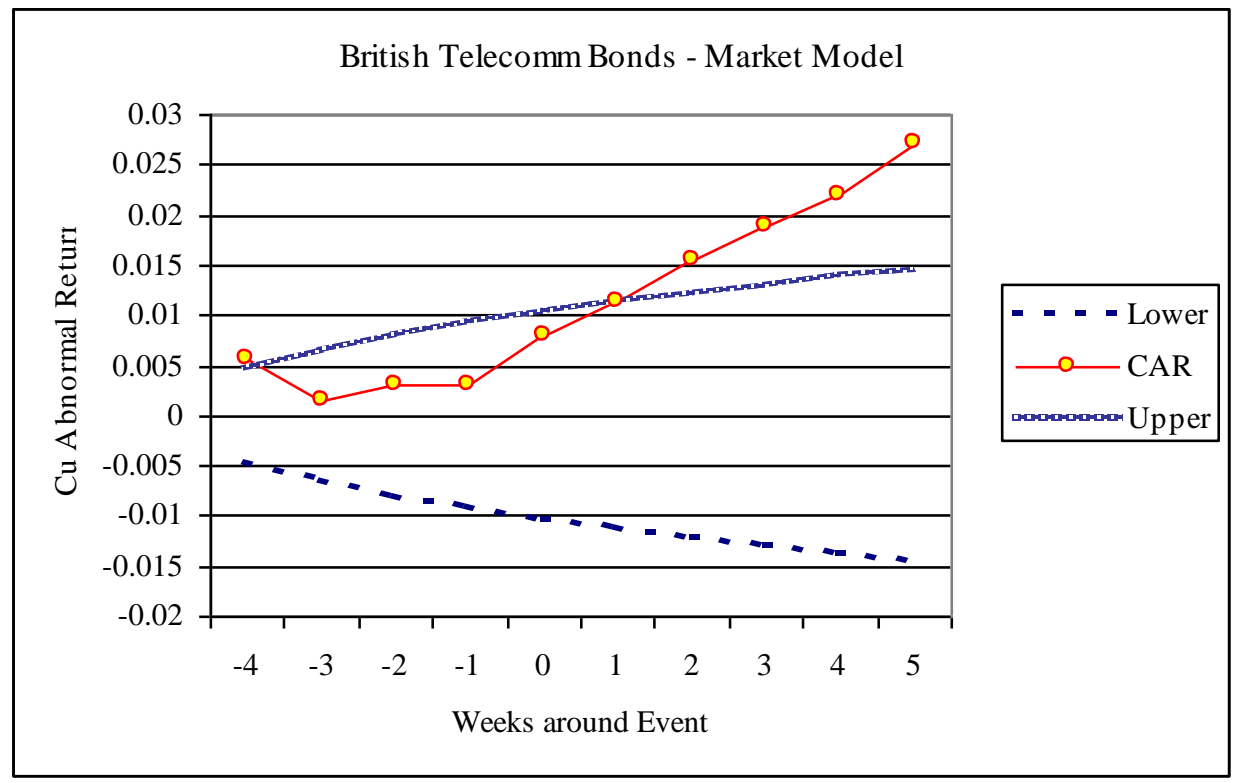

In the period after the announcement, there is a striking and statistically significant fall in BT's beta in relation to both the overall equity market and the telecommunications sector. Whether this can be (in part) attributed to the outsourcing deal is moot, given that the period includes the rights issue and, in particular, the flotation of MMO2. Whatever the reason, the market perceived British Telecommunications as less risky in the post-event period.

\section{Marks \& Spencer (M\&S)}

The two M\&S deals were examined separately. Neither produced discernible impacts on share prices using either event study or single index model methods. There is no apparent impact on bond prices. The capital markets appear indifferent to the two deals. As suggested above, it may be that the negative effects of increased gearing and the possibly low sale price achieved in the first deal are offset by the prior announcement of returning cash to shareholders and possibly higher implied values for the remaining real estate assets. 


\section{J Sainsbury's}

The two Sainsbury's structured sale and leaseback deals in 2000 are similar in structure, although the first and larger deal, Project Redwing/Highbury Finance, received much more attention than the second. Share-price reactions will be influenced by market assessments as to managerial ability to add value from the proceeds obtained (and the slight increase in gearing), since the funds raised were to be reinvested in the business in an attempt to improve return on capital.

Share-price reaction to Project Redwing appears to be negative. In both market and sector models, the cumulative abnormal returns are strongly statistically negative around and after the announcement date; there is a particularly strong negative reaction in the week of the announcement itself. There is a slight, but non-significant, increase in market beta after the deal was announced, but the main reaction seems to be to mark prices down in relation to both the overall market and other food retailers.

\section{$<$ Figure 5 near here>}

Figure 5: Sainsbury's cumulative abnormal equity returns

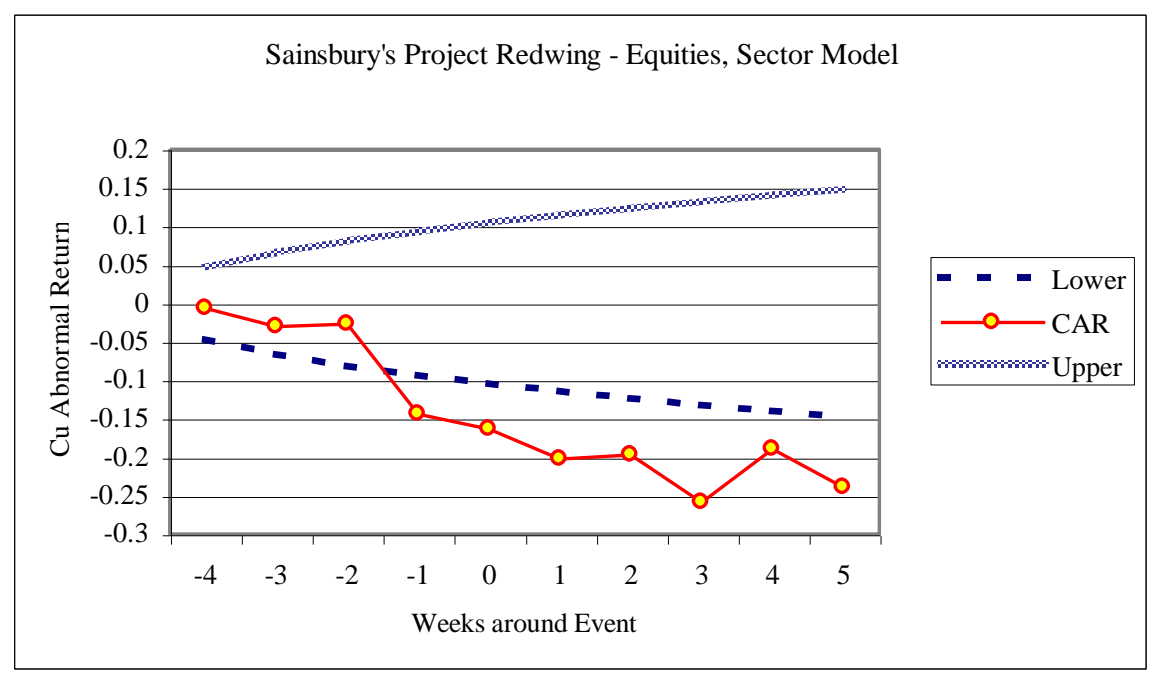

This negative response is not echoed in share-price movements around the time of the second deal. One can speculate on the difference in the reactions observed - changed market sentiment towards management or towards food retailing as a sector; the active 
promotion of the benefits of the structured sale and leaseback model; observation of the use of the capital proceeds. Given the similarity of the two deals and of their impact on the capital structure of the firm, the contrast in reactions is striking. Sainsbury's bonds seem unaffected by either deal.

\section{Shell Trading}

We anticipated that there would be little impact on Shell Trading's equity prices from the sale and leaseback of 180 petrol stations, given the size of the deal in relation to the market capitalisation of the company. (Even though the deal raised $£ 300$ million, the firm had a market capitalisation of $£ 46$ billion at the end of 2001.) Furthermore, the sale and leaseback was private and attracted little publicity and comment. The cumulative abnormal returns are weakly negative, but the statistical significance of this effect disappears quickly after the deal is completed. The data available on Shell's bonds behave strangely and seem curiously uncorrelated with gilt prices. The cumulative abnormal returns are weakly negative, which would be consistent with an increase in effective gearing; it would however, be dangerous to over-interpret this result.

\section{$<$ Figure 6 near here>}

Figure 6 Shell Trading cumulative abnormal bond returns

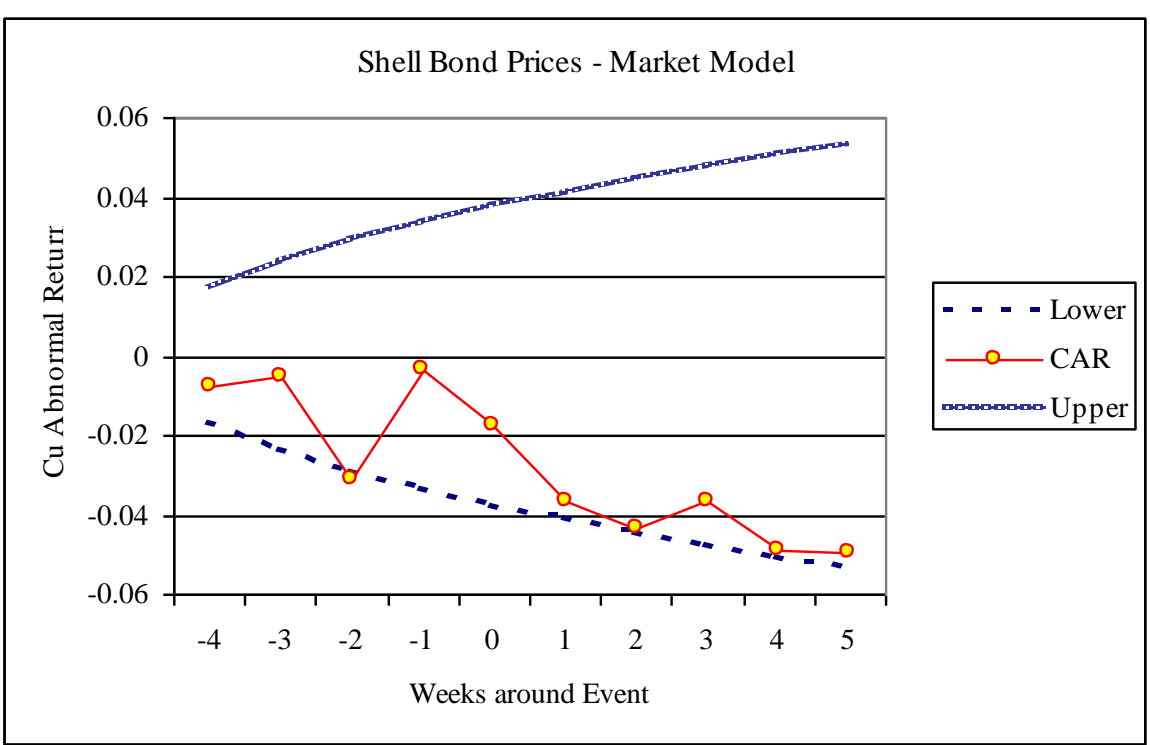




\section{Aggregate results}

In event studies, it is common to aggregate results across companies to investigate whether general types of reaction can be observed. This exercise was carried out for all the corporate real estate deals analysed here. However, as might be expected from the individual results discussed above, there was no evidence of a common impact. We repeated the exercise for the retail sector deals alone. There was again no evidence of a common pattern of behaviour, the net effect of deals being broadly neutral for both equity and bond prices. An apparent negative movement at the point of the announcement in the sector model seems to arise almost entirely to the market's negative reaction to the first of the Sainsbury's structured sale and leaseback deals. The implication seems to be that the capital-market impacts of restructuring of corporate real estate are highly conditional, depending on the particular nature of the deal, its effect on capital structure and the proposed use for the proceeds.

\section{CONCLUSION}

Our analysis sought to identify share and bond price movements linked to corporate real estate outsourcing or leasing deals, assuming that capital markets can judge the full impact of deals on the future risk and return of the firm and, thus, adjust their required return. This should result in a change in prices in relation to the market or the sector. The price changes will reflect stakeholders' assessments of the full benefits and costs of the deal, both financial and operational. It should be stressed that it may be very difficult to discern a relative price change in the general noise of market movement, particularly where the deal is relatively small in relation to the firm's overall operational scale or asset base, or where there are other events that would have share or bond price impacts. Nonetheless, general conclusions may be drawn.

First, two deals with apparently similar structures can have quite different impacts. Evaluation of the costs and benefits depends on the final impact on the capital structure resulting both from the deal and from use of the proceeds from that deal. Since a structured sale and leaseback is a debt liability, it will increase the gearing of the firm. The final capital 
structure, however, will vary greatly, depending on the use of the capital raised: to retire existing debt, to buy back shares, or to reinvest in the operational activity of the company. With higher final gearing, equity holders require higher returns to compensate for greater potential volatility and exposure to interest-rate (or rental-market) risk. Bondholders will need to consider the balance between potentially improved cash flow and the loss of security for their capital once the proceeds have been applied; adjustments to default and delinquency risk lead to changes in required returns and, hence, in prices.

Secondly, market reaction to the use of funds will depend on attitudes to the firm's operational efficiency, the quality of management and the prospects for the sector and the type of activity which the proceeds support. If management are out of favour with the markets, then providing more capital for investment in operations is likely to promote a negative reaction. Retaining capital in the firm is valid only if the market's anticipated return on that capital is greater than the returns the shareholders could get for comparably risky projects elsewhere; similarly, if the risk-adjusted returns from the firm's use of the capital are less than the implicit return on the real estate assets, then outsourcing deals will not add value to the firm. It is these contingent effects that need to be emphasised.

There is scope for more detailed work examining such deals. Analysis based on capital-market movements is problematic in this period because of the distorting effects of the dot.com and technology sector boom and bust. Some capital-market impacts may thus be obscured by the rapid changes in sentiment towards individual sectors. Furthermore, the limited number of case studies means that it is not possible to provide quantitative analysis of the criteria that lead to positive or negative impacts on share and bond prices. Nevertheless, the results set out above are consistent with prior US research on the impact of corporate real estate restructuring on share-price performance: there are potential benefits from such activity, but they cannot simply be assumed. There is no free lunch.

\section{ACKNOWLEDGEMENTS}

This paper draws on research funded by Boots Properties. We acknowledge the support and the valuable comments of Mark Chivers and Louise Finlay. We also received helpful 
comments and suggestions from the publishing editor and anonymous reviewers. The views expressed here are, however, those of the authors alone. We are grateful for the insights of our colleague Charles Ward. 
Table 1: UK outsourcing deals chosen for analysis

\begin{tabular}{|c|c|c|c|c|c|c|}
\hline Company & Buyer & Type of Deal & $\begin{array}{l}\text { Number of } \\
\text { Properties }\end{array}$ & Amount Raised & Use of Funds & Completion Date \\
\hline Abbey National & Mapeley & 'Full' outsourcing & 1,320 & $£ 457.5 \mathrm{~m}$ & $\begin{array}{l}\text { Reinvest in } \\
\text { business? }\end{array}$ & October 2000 \\
\hline J Sainsbury's & Highbury SPV & $\begin{array}{l}\text { S\&L and } \\
\text { securitisation }\end{array}$ & 16 & $£ 335 m$ & $\begin{array}{l}\text { Reinvest in } \\
\text { business }\end{array}$ & March 2000 \\
\hline J Sainsbury's & Highbury SPV & $\begin{array}{l}\text { S\&L and } \\
\text { securitisation }\end{array}$ & 10 & $£ 232 \mathrm{~m}$ & $\begin{array}{l}\text { Reinvest in } \\
\text { business }\end{array}$ & July 2000 \\
\hline Kingfisher & $\begin{array}{l}\text { London \& } \\
\text { Regional and } \\
\text { Goldman Sachs }\end{array}$ & Sale \& leaseback & 182 & $£ 614 \mathrm{~m}$ & Reduce debt & August 2001 \\
\hline Marks \& Spencer & Topland Group & $\begin{array}{l}\text { ‘Flexible' sale \& } \\
\text { leaseback }\end{array}$ & 78 & $£ 348 m$ & $\begin{array}{l}\text { Fund share } \\
\text { buybacks }\end{array}$ & October 2001 \\
\hline Marks \& Spencer & Amethyst SPV & $\begin{array}{l}\text { S\&L and } \\
\text { securitisation }\end{array}$ & 59 & $£ 331 \mathrm{~m}$ & $\begin{array}{l}\text { Fund share } \\
\text { buybacks }\end{array}$ & December 2001 \\
\hline Shell & $\begin{array}{l}\text { London \& } \\
\text { Regional and } \\
\text { Rotch }\end{array}$ & Sale \& leaseback & 180 & $£ 300 m$ & $\begin{array}{l}\text { Reinvest in } \\
\text { business }\end{array}$ & December 1999 \\
\hline
\end{tabular}

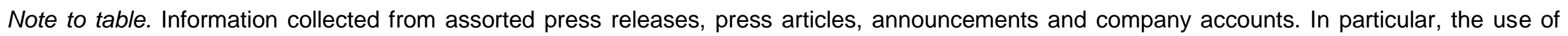
funds is that stated in press or publicity - actual use of funds may have been different. 


\section{REFERENCES}

${ }^{1}$ For reviews see Rodriguez, M. and Sirmans, C. (1996) 'Managing Corporate Real Estate: Evidence from the Capital Markets', Journal of Real Estate Literature, Vol. 4, pp. 13-33; Lizieri, C., Ward, C. and Lee, S. (2001) 'Financial Innovation in Property Markets: Implications for the City of London', Final Report: Corporation of London. A discussion of European corporate outsourcing can be found in Nappi-Choulet, I. (2002) 'Corporate Property Outsourcing in Europe: Present Trends and a New Approach for Real Estate Economics', paper presented to the IPD European Property Strategies Conference, Wiesbaden, May 2002.

${ }^{2}$ This differs from practice in the USA, where, under US GAAP, the properties must remain on the balance sheet and a corresponding liability be raised against them.

${ }^{3}$ Beattie, V., Goodacre, A. and Thomson, S. (2000) 'Recognition versus Disclosure: An Investigation of the Impact on Equity Risk Using UK Operating Lease Disclosures', Journal of Business Finance \& Accounting, Vol. 27, Nos 9-10, November-December, pp. 11851224.

${ }^{4}$ See for example Moody's Investors Service (2001) ‘European Telecommunications Operators' Use of Sale and Leaseback Transactions Can Pressure Ratings', Special Comment, October 2001, Report 70915, London.

${ }^{5}$ See Hill, M. (2001) 'Corporate Real Estate: Its Role in Maximising Shareholder Value', Journal of Corporate Real Estate, Vol. 3, No. 4, pp. 335-345.

${ }^{6}$ Gibson, V. and Barkham, R. (2001) 'Corporate Real Estate Management in the Retail Sector: A Study of the Relationship between the Management of the Corporate Real Estate and Corporate Performance', Journal of Real Estate Research, Vol. 22, Nos 1-2, pp. 107127.

${ }^{7}$ We suspect that many such decisions are based on somewhat uncertain or speculative figures. Further, many of the outsourcing deals we have examined have been motivated more by capital than by revenue impacts. 
${ }^{8}$ The Abbey National deal has been featured in more detail in a previous issue of the Journal of Corporate Real Estate: see Asson, T. (2002) 'Real Estate Partnerships: A New Approach to Corporate Real Estate Outsourcing', Journal of Corporate Real Estate, Vol. 4, No. 4, pp. 327-333.

${ }^{9}$ Adams, A. and Clarke, R. (1996) 'Stock Market Reactions to Sale and Leaseback Announcements in the UK', Journal of Real Estate Research, Vol. 13, pp. 31-46.

${ }^{10}$ In this and subsequent figures, the lower and upper bounds show the 95 per cent significance lines. When the cumulative abnormal returns move above (below) those lines, the authors are 95 per cent confident that there has been a positive (negative) reaction to the event. 